\title{
THE MODEL OF INTEGRATIVE MANAGEMENT OF RURAL SOCIAL INFRASTRUCTURE DEVELOPMENT
}

Vilma ATKOČIŪNIENĖ, Prof. Dr Business and Rural Development Management Institute, Aleksandras Stulginskis University, Universiteto St. 10-402, Akademija, Kaunas distr., Lithuania, vilma.atkociuniene@ asu.lt (corresponding author)

Ilona KIAUŠIENE், Assoc. Prof. Dr Business and Rural Development Management Institute, Aleksandras Stulginskis University, Universiteto St. 10-408, Akademija, Kaunas distr. Lithuania, ilona.kiausiene@asu.lt

One of the most difficult problems encountered by social infrastructure development management in various countries of economic development is the search for RSI management interactions at the national, regional and local (municipal, neighborhood) levels. Traditional solutions to RSI development do not create opportunities for the coherence, viability and resilience of rural development. This article describes integrative management of rural social infrastructure (RSI), provides the analysis of RSI management processes and explanation of "triple bottom line", determination of main principles required in order to achieve sustained development of the region. The main research objective, namely, creation of an integrative rural social infrastructure management model reached. The integrative RSI management conception based on four- tier governance cycle "plan-do-check-act" and internal governance functions. The functions RSI management are determination of consumer demand for RSI services and strategic development goals; planning of RSI services, means and results; organization of RSI services supply; horizontal and vertical coordination of RSI activities; assessment of RSI services consumers' opinion and community sustainability; supervision and evaluation of RSI activities. The main research methods were used: analysis and generalization of scientific literature, logical and systematical reasoning, graphic presentation of comparison, abstracts and other methods.

Keywords: social infrastructure development, integrative management of rural social infrastructure.

\section{INTRODUCTION}

The rural social infrastructure (hereinafter referred to as the RSI) is an integral part of the State infrastructure. "Present infrastructure operation is characterised by: governance based on unmanaged growing demand, which is both inefficient and ultimately unsustainable; lack of integration of the end-users, in terms of the variety of their wants, needs and behaviours; separate and parallel delivery of different infrastructure streams prohibiting joint solutions" (Roelich, Knoeri et al., 2015, p. 40). According to the integrated evaluation of RSI conditions of Lithuania the state faces some difficulties in ensuring territorial and social cohesion between separate districts (Atkociuniene et al., 2015). RSI are complex and dynamic. The complex RSI requires multi - level management. Referring just a few - households, organizations, sectors, they are managed in one or another way individually. There are still no clear limits of management between the different institutions activity areas, overlapping of the functions performed by the roster, weak coordination. Integrated management system can to provide the sustainability. Sustainability management is about managing people - not the environment or the money or the built society as such. The goal is to include the integration of various RSI sectors, levels of authorities, integration of tools and instruments, stakeholder's actions (Integrated Management System..., 2008).

Scientific problem: RSI development is not sustainable. RSI's development management is non-systematic, involving many actors, and solutions are low-vertically and horizontally integrated. Conventional RSI management solutions are insufficiently incorporated and not directed towards the development of rural areas; they are made and implemented without paying reasonable attention to the long-term perspective, interactions between governance levels, sectors, activities and stakeholders. The theoretical fundamentals are unusable for creation of integrative RSI management opportunities. For this reason the integrative rural social infrastructure management model shall defined and justified.

The object of research - management of rural social infrastructure.

The aim of research - to create the integrative rural social infrastructure management model.

The main research methods: analysis and generalization of scientific literature, logical and systematical reasoning, graphic presentation of comparison, abstracts and other methods.

Copyright (C) 2017 The Authors. Published by Aleksandras Stulginskis University. This is an open-access article distributed under the terms of the Creative Commons Attribution License (CC-BY 4.0), which permits unrestricted use, distribution, and reproduction in any medium, provided the original author and source are credited. 


\section{THE CONCEPTUAL FRAMEWORK OF INTEGRATIVE MANAGEMENT OF RURAL SOCIAL INFRASTRUCTURE DEVELOPMENT}

Conceptual framework of the article is formed by different scientific researches conducted at various times and data included into them, which have analyzed service delivery policies (Mcloughlin, Batley, 2012), social infrastructure problems (Berry, 2011; Gladstone social infrastructure..., 2011), the factors that determine the management of rural social infrastructure (Kresl, 1995; Juozaitienè, Staponkienè, 2002; Čiegis, 2004; Posayanant, Chareonngam, 2010; Pranulis, Pajuodis ir kt., 2012; Social Connection, Community..., 2012; Burgis, Šimanskienė, Kutkaitis, 2014), RSI management functions and principles (Helling, Serrano, Warren, 2005; WBOP, 2009; Teriman, Yigitcanlar, Mayere, 2011; Atkociuniene et al., 2015).

The social infrastructure has no single definition. In practise, according the social infrastructure planning tool project, prepared by Joanne Kyrkilis (2012) social infrastructure is synonym to social resources. Social infrastructure can be defined as: "processes, programs, events, services, networks and activities that support individuals and families to meet their social and personal needs in a particular place through personal growth, social interaction, social services support and community development”,(Berry, 2011). Infrastructure is a means, which built, maintained and expanded in order to enable the functioning of society (Roelich, Knoeri et al., 2015). In the article rural social infrastructure defined as: is a territorial and spatial system of interrelated economic and social activities and relations, forming particular conditions for functioning of ecosystems, creation of human, physical and social capital to be used by individuals and society in order to fulfil individual and social needs (Atkociuniene et al., 2015).

Mcloughlin, C., Batley, R. (2012) identified 4 types of technical characteristics that affect service delivery policies within and between sectors:

- nature of the good: the service may be provided on the market or necessary public intervention;

- market failure: what are the rational public interventions;

- orientation to the results: how the relationship between control and accountability affects the organization and delivery of services;

- the demand: as a service provision environment, it influences modes of controlling the use of services and provision of services.

The "principle of integration" is at the core of sustainable development. The "narrow" understanding: integration of all environmental effects when considering a new project (IPPC-directive, 2007). The "broad" understanding: integration of environmental/sustainable development objectives into the development process, and thus into the policy definition and implementation of various economic and social sectors. Rio declaration principle 4. "In order to achieve sustainable development, environmental protection shall constitute an integral part of the development process and cannot be considered in isolation from it." (1992). Integration doesn't just happen - it must be planned. The integration plan should define and identify all interface events, interrelationships between tasks and hardware subsystems, and potential interface problems.

K. Roelich, C. Knoeri et al. (2015) identified the novel approach of infrastructure. The research results shows that to achieve long-term sustainability, infrastructure needs to be planned and operated to provide essential service delivery at radically decreased levels of resource use. "This new approach will need to: incorporate the end-user, in terms of their wants and behaviours; focus on the service provided; use information and communication technologies more effectively; integrate the operation of different infrastructure systems; be governed in a manner that recognises the complexity and interconnectedness of infrastructure systems; and rethink current infrastructure valuation" (Roelich, Knoeri et al., 2015).

RSI is determined by the development of appropriate local resources (formation and disclosure), while the latter is a crucial twofold source: socio-cultural system of internal opportunities; internal and external environment provides the strategic breakthrough conditions. The rural area as a territory has the following characteristics:

- Openness - both urban and rural areas are never very isolated from their external environment, and the larger the territory, the connections and the influence of the external environment are more diverse. R. Putman (1995) notes that openness creates a complex structure of interaction between the territory and its environment.

- Complexity - the RSI is a complex structure, managed at various levels and the degree of power, interacting at different levels of time and space to a non-linear manner (Paliulis, Činčikaitè, 2011).

- Dynamism - the development of RSI depends on internal and external environmental conditions and their interactions. The latter features or the environment, in which SI objects function, creates competition between the RSI and the city SI, the distribution of service users and providers.

Analysing scientific work that presents the problem of RSI environmental factors, one can notice that the authors choose two sections of the analysis: they examine the complexity of environmental factors or the group of factors of one kind. I. Lengyel (2003), G. Bristow (2005) distinguishes environmental factors according to the impact on development, J. Reiljan, K. Timpmann, K. Olenko (2003) - on the possibility of controlling factors, etc. One of the most commonly used scientific clasifications is the internal and external factors.

Management of RSI takes place in an open system. The peculiarities of RSI management are determined by social and cultural, political and legal, environmental (natural) and economic factors (often are considered as a priority) (Fig. 1). 
RSI development is predetermined by the internal and external environmental factors, which could be classified as psychological, social-cultural, economical, natural, legal-political, etc. RSI development area is subjected to internal distant and close environment (for example, when consumer's behaviour depends on personal psychological factors, motives, experiences, etc.) and the external distant and close environment (political environment, legal regulations, global trends, etc.). Describing the influence of internal environmental factors on the development of RSI is very complicated as the social infrastructure of each village, as a successful management of the socioeconomic system, is possible by revealing the potential of the development of the area. First of all, the human being who is able to see all the conditions of a strategic breakthrough, all development opportunities and properly use the local resources of the locality, create competitive goods and services in the area, meet the needs of consumers and create good living conditions, new impulses for the sustainable development of the community.

A dynamic environment changes not only the concept of infrastructure as an object, but also changes that affect the formation of infrastructure. One of the main environmental factors driving the development of RSI is the needs of the rural community, and special attention should be paid to the inclusion of people in the RSI management process. RSI service users are running RSI service demand and ensure the functioning of RSI objects. The RSI has a structure of hierarchies according to the intensity of resident needs. The need classification structure is in accordance with the consumption benefits and frequency.

One of the management functions are social infrastructure planning - new infrastructure creation and phasing out of outdated one when cost-effective. Infrastructure integration is efficient resources use, which can support the infrastructure sustainability. Many of the individual components of infrastructure planning and design are often inter-related, influencing each upon another - an integrated approach is required to deliver successful solutions. The way to do this is to integrate infrastructure - roads, telecommunication lines, waste systems, schools, community centres - as effective and integrated infrastructure policies are necessary to foster integrated economic development (Kukobat, 2010).

\begin{tabular}{|c|c|c|c|}
\hline $\begin{array}{l}\text { The internal } \\
\text { environmental } \\
\text { factors }\end{array}$ & \multicolumn{2}{|c|}{$\begin{array}{l}\text { ECONOMICAL FACTORS } \\
\text { rate, unemployment rate, wage level, energy supply and } \\
\text { nue and expenditure }\end{array}$} & $\begin{array}{l}\text { The external } \\
\text { environmental } \\
\text { factors }\end{array}$ \\
\hline $\begin{array}{l}\text { Taxation and } \\
\text { legislation, } \\
\text { state and } \\
\text { municipal } \\
\text { government } \\
\text { stability and } \\
\text { innovation, } \\
\text { special } \\
\text { programs, } \\
\text { laws, etc. }\end{array}$ & $\begin{array}{l}\text { Financial ar } \\
\text { RSI service providers and consumers } \\
\text { approach } \\
\text { Municipalities, } \\
\text { organizations RSI } \\
\text { legal acts }\end{array}$ & 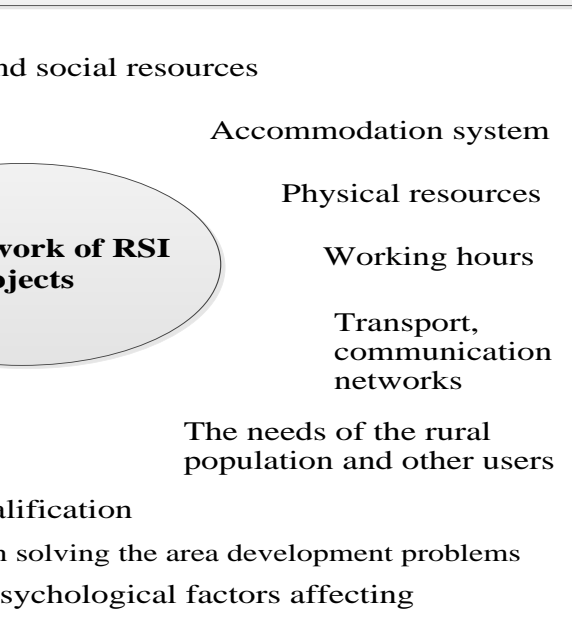 & $\begin{array}{l}\text { SOCIAL, } \\
\text { CULTURAL } \\
\text { FACTORS } \\
\text { The dynamics } \\
\text { of family } \\
\text { creation, } \\
\text { population, } \\
\text { demographic } \\
\text { structure, } \\
\text { consumer } \\
\text { activity and } \\
\text { etc.. }\end{array}$ \\
\hline \multicolumn{2}{|c|}{$\begin{array}{l}\text { ENVIRONMENTAL (NATURAL) FACTORS } \\
\text { Green infrastructure, protected areas, ecology of } \\
\text { production and consumption }\end{array}$} & \multicolumn{2}{|c|}{$\begin{array}{l}\text { SCIENTIFIC, TECHNOLOGICAL FACTORS } \\
\text { Total public expenditure on research, productivity } \\
\text { growth due to automation, Internet access, } \\
\text { telecommunication infrastructure, etc. }\end{array}$} \\
\hline
\end{tabular}

Figure 1. Factors that determine the management of rural social infrastructure

Source: author's construction based on Kresl (1995); Čiegis (2004); Posayanant, Chareonngam (2010); Pranulis, Pajuodis et al. (2012); Burgis, Šmanskienè, Kutkaitis (2014); Atkociuniene et al. (2015).

According to infrastructure expert M. Kukobat (2010) is necessary infrastructure integration includes a few dimensions:

- National infrastructures integration (economy of scale, security of infrastructure products and services, regional competitiveness); part of infrastructure developed in the territory of one country can be used to meet infrastructure requirements of other(s);

- Inter-operability and inter-connectivity;

- Inter-modality;

- Multi-level and multi-stakeholder inclusion (different interests to reconcile to reach balanced development);

- Integration with related economic sectors; 
- Multi-sector integration (integrated development planning and design tool for optimizing the overall infrastructure development).

Sustainable RSI can contribute to the achievement of sustainable development themes, which is the "triple bottom line" by embracing the following objectives (DETR, 2000; Peri, 2012; Ochieng, Wynn and others, 2014):

- $\quad$ being more profitable and competitive;

- delivering building and structures that provide greater satisfaction, well-being and value to customers and users;

- $\quad$ respecting and treating its stakeholders more fairly;

- $\quad$ enhancing and better protecting the natural environment;

- minimising its consumption of energy (especially carbon-based energy and natural resources.

"Triple bottom line" sustainability approach defines as social, economic and environmental pillars of sustainable development. The sustainable principle emphasise the interconnections and interdependencies between the pillars and the conflicts and trade-offs (Gibson, 2001).

According to L. Rydén (2008), the most difficult part of sustainable development management is integration. Integrated management implemented at high speed in the business world because of environmental, social and economic aspects of management in one system becomes increasingly important prerequisite for effective decisionmaking. Integration is also essential for RSI's sustainable development management. This requires proper management of the development of rural areas and the implementation of appropriate infrastructure projects. Project level of integration can be achieved by collecting all the projects, which deal with a particular problem, the project portfolio or collection (portfolio). Problems can be functional, such as waste management or energy supply; territorial, for example, include the territory of the neighbourhood or park; development, for example, the development of a new industry. Rural areas have different programs that are more or less composed of such project portfolios.

The project "European Cities Management 25" (MUE25) has developed a five-tier governance cycle based on the "plan-do-check-act” Deming cycle for Urban Sustainable Development, which could be adapted for RSI management. It has been adapted for many purposes, including cleaner production and environmental management directly related to urban management projects (Rydén, 2008). The integrated management system consisting of 5 steps: baseline review; target setting; political commitment; implementation and monitoring; evaluation and reporting (Integrated Management System..., 2008).

According to the authors of the article, RSI Integrated Management is the application of management processes that cover some or all of the major components: volumes, schedules, costs, risks, quality and resources.

There were identified the six integrative functions that act across those components:

1. Location and community profile, determination of consumers demand for RSI services and strategic development.

2. RSI development: analyses of services, means and results, evaluation and planning.

3. Organization of provision of RSI services, provision of services, creation of social amenities.

4. Horizontal and vertical coordination of RSI activities.

5. Assessment of RSI services consumer's opinion and community sustainability.

6. RSI condition, performance monitoring and evaluation requirements of infrastructure capacity and quality setting.

The overall goal of the integrative management functions are sustainable communities. Each integrative function brings together aspects of the fundamental delivery components. RSI and its management is a complex process characterized by the hierarchical pattern (see Figure 2). The process in local level lasts three, in European level - seven years. Every year, a detailed action plan should be prepared. One of the most important goals of the RSI management at the local level is to satisfy social needs of rural residents in order to ensure provision of high quality services in terms of the distance, flexibility and price, and at the regional and national levels to establish proper requirements for implementation of abovementioned actions in the course of sustainable environment creation.

The integrative management of the RSI facilities could ensure sustainable development of a territory. Significant attention should be paid to conditions for the development of social and economic public activities, vision, mission and performed functions of rural territories, management principles, social development of existing and future generations, and satisfaction of the demand for RSI services.

In order to improve the interactions of the RSI governance levels, it is necessary to pursue synergies in three main directions in accordance with the principles of the RSI:

- political synergy - helps to integrate the elements of RSI and gain positive influence, helps to ensure the creation of socio-economic benefits through the use of infrastructure potential and result-oriented policymaking, sharing of responsibilities;

- values synergy - allows recognition of RSI as an exceptional complex phenomenon and implementation of the principle of sustainability based on trust;

- institutional synergy - the government, while implementing its core functions of coordination and cooperation, adheres to the principle of transparency. 


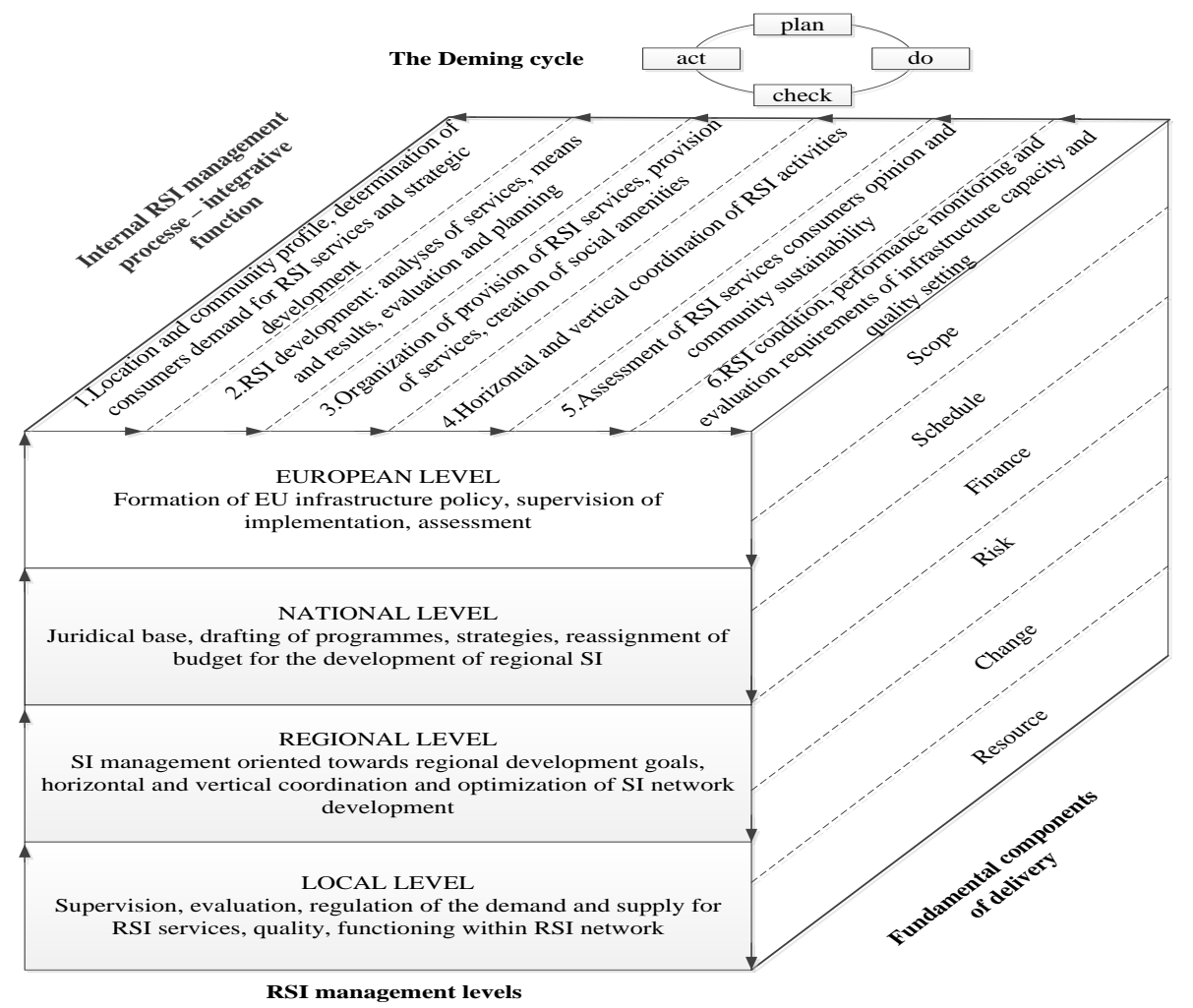

Figure 2. Schematic diagram of rural social infrastructure integrative management

Source: author's construction based on Jakubavicius, Strazdas ir kt. (2003); Augustinaitis (2003), Planning Sustainable Communities - A Green Infrastructure (2005); Rydén (2008); Rydén (2008); Integrated Management System... (2008); A social infrastructure plan... (2006); Segaloviciene (2012; Atkociuniene et al. (2015) Roelich, Knoeri et al. (2015).

\section{CONCLUSIONS AND DISCUSSION}

1. The development of RSI is a process whereby values and a sustainable community are created more qualitatively and rapidly. In addition, this is an activity where municipalities, local government officials, rural communities influence RSI's development process for the benefit of society as a whole. RSI's development is driven by its internal and external environmental factors, and integrated management can help achieve community sustainability.

2. The integrative rural social infrastructure management model includes integrative functions, fundamental components of delivery in different RSI management levels: scope, schedule, finance, risk, change, resource. Different types of synergies - political, values, institutional, can help to improve the interactions of the RSI governance levels.

3. The integrated management system of RSI consisting of 6 steps: 1) location and community profile, determination of consumer demand for RSI services and strategic development goals; 2) RSI development (planning of services, means and results); 3) organization of RSI services supply; 4) horizontal and vertical coordination of RSI activities; 5) assessment of RSI services consumers' opinion and community sustainability; 6) RSI condition, performance monitoring and evaluation requirements of infrastructure capacity and quality setting. The steps have to be based on the "plan-do-check-act" Deming cycle for RSI sustainable development. Management levels are interrelated due to the direct impact of one or another decision made at one level on the balancing of supply and demand for RSI services required in order to ensure prosperity of consumers.

4. In order to ensure sustainable development of the site, preserving the rural areas for future generations, it is necessary to continuously investigate, analyse, and evaluate the state of the RSI. The stakeholder's involvement and communication, organisational setup based on "triple bottom line" are necessary to ensure the process. The political, values and institutional synergistic functioning of RSI helps to achieve the efficiency and ensure the availability of RSI services that meet the needs of the population and future generations.

\section{REFERENCES}

1. A Social Infrastructure Plan for Voluntary and Community Action in the Milton Keynes and South Midlands Growth Area. 2006. Strong Communities. MKSM Social Infrastructure Group. England.

2. Atkočiūnienè, V., Aleksandravičius, A., Kiaušienė, Vaznonienė, G., Pakeltienè, R., Lukè, R. 2015. Kaimo socialinès infrastruktūros vystymas siekiant užtikrinti teritorinę ir socialinę sanglauda. Mokslo studija, Kaunas, Akademija, p.224, [Improvement of rural social infrastructure for the territorial and social cohesion]. [In Lithuanian]

3. Augustinaitis, A. 2003. Valdymo komunikacija: ziniu visuomenes itaka viesajam administravimui. Informacijos mokslai, T. 27. p. 9-22. [Management communication: the knowledge society influence on public administration]. [In Lithuanian] 
4. Berry W., 2011. The Art of the Commonplace: The Agrarian Essays, p.146.

5. Bristow, G. 2010. Critical Reflections on Regional Competitiveness. Theory. Policy. Practice. Abington: Routledge

6. Burgis, D., Šimanskiene, L., Kutkaitis, A. 2014. Lietuvos kaimo vietoviu darnus vystymas. Klaipeda: Klaipedos universitetas.[Sustainable development of Lithuanian rural areas]. [In Lithuanian]

7. Čiegis, R. 2004. Ekonomika ir aplinka: subalansuotos plètros valdymas. Kaunas: VDU leidykla. [Economics and the Environment: Sustainable Development Management] [In Lithuanian]

8. DETR. 2000. Building a better quality of life: A Strategy for more sustainable construction. Department of the Environment, Transport and the Regions: London.

9. Gaudreau, K., and Gibson, R. B., 2010. Illustrating integrated sustainability and resilience based assessments: a small-scale biodiesel project in Barbados. Impact Assessment and Project Appraisal, Vol. 28 (3), pp. $233-243$. https://doi.org/10.3152/146155110X12772982841122

10. Gibson, RB. 2001. Sustainability appraisal for sustainable development: integrating everything from jobs to climate change. Impact Assessment and Project Appraisal, No.19(1), pp. 95-106.

11. Gladstone Social Infrastructure Strategic Planning Study: Gladstone region social infrastructure e-voluntary industry contributions framework. 2011. Available at: http://www.deedi.qld.gov.au/cg/resources/report/gladstone-sisp.pdf. (Accessed on 2017/11/07)

12. Integrated Management System - towards local and regional sustainability. 2008. Edit by Claesson, A., Talve, L. Union of the Baltic States commision on Environment, Available file:///C:/Users/Vartotojas/Downloads/MUE25_IntegratedManagement.pdf (Accessed on 2017/11/07)

13. Jakubavičius, A., Strazdas, R., Gečas, K. 2003. Inovacijos: procesai, valdymo modeliai, galimybes. [Vilnius: Lietuvos inovaciju centras. [Innovations: processes, management models, opportunities]. In Lithuanian].

14. Kresl, P. K. 1995. The Determinants of Urban Competitiveness. A Survey in P.K. Kresl and G. Gappert, (Eds.). North American Cities and the Global Economy. Beverly Hills: Sage, pp. 45-68.

15. Kukobat, M. 2010. Integrated Infrastructure planning. Infrastructure and Energy Unit, Regional Cooperation Council Secretariat, Newsletter 2/2010.

16. Lengyel, I. 2003. Economic Growth and Competitiveness of Hungarian Regions. Paper prepared for „, Reinventing Regions in the Global Economy" RSA Conference, 12th - 15th April 2003, Pisa, Italy, p. 18.

17. Mcloughlin, C., Batley, R. 2012. The Effects of Sector Characteristics on Accountability Relationships in Service Delivery. ODI Working Paper 350. London: Overseas Development Institute. Available at: http://www.odi.org.uk/sites/odi.org.uk/files/odiassets/publications-opinion-files/7790.pdf (Accessed on 2017/11/07)

18. Ochieng, EG., Wynn, TS., Zuofa, T., Ruan, X., Price ADF., Okafor, C. 2014. Integration of Sustainability Principles into Construction Project Delivery. Architectural Engineering Ochieng et al., Journal of Architectural Engineering Technology, No. 3. https://doi.org/10.4172/2168-9717.1000116

19. Paliulis, N., Činčikaite, R. 2011. Miesto konkurencingumo sąvokos ir jị lemiančių veiksnių analizė. Ekonomika ir vadyba, Nr.16, pp. 258-16. [The concept of urban competitiveness and its determinants]. [In Lithuanian].

20. Peri, M., 2012. A territorial understanding of sustainability in public development. Environmental Impact Assessment Review, Vol. 32, pp. 61-73. https://doi.org/10.1016/j.eiar.2011.03.004

21. Planning Sustainable Communities - A Green Infrastructure Guide. 2005. EQoL Group for Milton Keynes and the South Midlands April 2005.

22. Posayanant, S.; Chareonngam, C. 2010. Prototype KPIs for rural infrastructure development: The practice of sub-district local governments. International Journal of Productivity and Performance Management. Available at: http://www.emeraldinsight.com/journals.htm/journals.htm?issn=1741-0401\&volume=59\&issue=8\&articleid=1891501\&show=html (Accessed on 2017/11/07)

23. Pranulis, V.; Pajuodis, A.; Urbonavičius, S.; Virvilaite, R. 2002. Marketingas. [In Lithuanian].The Baltic PRESS.

24. Putnam, R. D. 1995. Bowling Alone: America's Declining Social Capital. Journal of Democracy, No. 6(1), pp. 65-78. https://doi.org/10.1353/jod.1995.0002

25. Reiljan J., Timpmann, K., Olenko, K., 2003. Key issues in developing the public administration system in Estonia before joining the European Union. Tartu Ulikooli majandusteaduskonna toimetiste seeria, No.17, pp. 68.

26. Rio Declaration on Environment and Development 1992 United Nations (UN) Available at: http://www.jus.uio.no/lm/environmental.development.rio.declaration.1992/portrait.a4.pdf (Accessed on 2017/11/07)

27. Roelich, K., Knoeri, C., Steinberger, J., K., Varga, L., Blythe, P., T., Butler, D., Gupta, R., Harrison, G., P., Martin, C., Purnell, P. 2015. Towards resource-efficient and service-oriented integrated infrastructure operation. Technological Forecasting and Social Change, Vol. 92, pp. 40-52.https://doi.org/10.1016/j.techfore.2014.11.008

28. Rydén, L., 2008. Integruoto valdymo metodai siekiant darnaus vystymosi miestuose ir gyvenvietèse. Urbanizacijos studijos ir darnaus vystymosi mokslai Upsalos darnaus vystymosi centras Upsalos universitetas, 2008. [Integrated management methods for sustainable urban and rural development]. [In Lithuanian].

29. Segalovičienè, I. 2012. Vertinimo geba ir jos kūrimas ị rezultatus orientuoto valdymo kontekste. Viešoji politika ir administravimas, No. 11(3), pp. 420-433. [Valuation and its development in the context of results-oriented management]. [In Lithuanian].

30. Social Connection, Community Wellbeing and Good Practice. 2012.

31. Social infrastructure planning tool project. Prepared by Joanne Kyrkilis, May 2012.

32. Teriman, S., Yigitcanlar, T., Mayere, S., 2011. Social Infrastructure Planning and Sustainable Community: Example from South East Queenslad, Australia. Proceedings of the Business and Social Science Research Conference 2011, pp.1-12, Novotel. 
33. The IPPC Directive. 2007. Revision of the IPPC Directive. Towards an improved policy on industrial policy. Available at: http://ec.europa.eu/environment/archives/air/stationary/ippc/ippc_revision.htm (Accessed on 2017/11/07)

34. WBOP (Western Bay of Plenty). 2009. Social Infrastructure Planning Framework. Western Bay of Plenty. 